\title{
2 \\ PHILOSOPHICAL, ETHICAL, AND AESTHETIC: \\ Values in Shadow Puppet Theatre (Wayang) Performance
}

Soetarno Dwijonagoro

\begin{abstract}
Abstrak
Pertunjukan wayang sering dipandang sebagai bahasa simbol kehidupan yang lebih spiritual daripada yang tampak di alam. Konsepsi implisit dalam pawayangan meliputi sikap atau pandangan tentang esensi kehidupan, asal dan tujuan hidup, hubungan antara manusia dengan Tuhan, hubungan antara satu orang dan yang lain, dan hubungan antara manusia dan alam . Sebuah studi tentang nilai-nilai filosofis yang terkandung dalam pagelaran wayang dapat dilakukan dengan menggunakan berbagai aspek yang berbeda yaitu: Aspek Metafisik, aspek etis, aspek epistemologis, dan mistisisme.
\end{abstract}

Aspek metafisik mengambil sebagai titik awal keberadaan manusia dan alam sebagai entitas nyata yang dapat ditangkap oleh panca indera. Aspek etika mencoba untuk memahami mengapa kita harus mengikuti prinsip-prinsip moral tertentu, atau bagaimana kita harus mengambil sikap yang bertanggung jawab terhadap berbagai prinsip-prinsip moral. Aspek epistemologis, menghadapi banyak pengetahuan yang perlu diuji, dengan harapan bahwa jika kita menemukan kebenaran dari suatu pengetahuan yang akan meningkatkan derajat kepastian dan akhirnya tingkat keyakinan kebenaran.

Total pemahaman Spiritual Mistisisme adalah suatu kedekatan dan penuh emosi dalam keberadaan realitas mutlak yang penuh rahasia. Sehingga pertunjukan wayang kulit adalah suatu pertunjukan yang lebih dari sekedar sebuah pertunjukan, melainkan memberi makna bagi kehidupan masyarakat

Kata Kunci : metafisik, etis, epistemologis, spiritual mistisisme.

\section{BACKGROUND}

The Indonesian community, and especially those communities to which the shadow puppet (wayang) culture belongs, know and understand shadow puppet theatre. To some wayang proponents and cultural observers, to understand wayang means to know their own lives. The stories presented in wayang performances are a reflection of their own lives. It is not uncommon for them to identify with particular wayang figures and to use the characters of these figures as an example for their own ac- tions. Furthermore, a wayang kulit performance is more than just a show; it gives meaning to people's lives.

Hence, at every performance of wayang kulit, people usually discuss the meaning of the story and the events contained within the story. The guidance or advice contained in the story can lead to a deeper understanding so that the contents of the story can easily be detached from the form of a wayang performance and become a topic for discussion or research. In other words, wayang figures and the events por- 
trayed in a wayang performance can be understood symbolically.

Wayang performances are often viewed as the language of symbols of a life that is more spiritual than physical in nature. Therefore, to proponents of wayang or members of the wayang community, a wayang performance contains conceptions that are used as a guideline for the attitudes and actions of a particular community. The conceptions implicit in a wayang performance include attitudes or views about the essence of life, the origin and purpose of life, the relationship between man and God, the relationship between one man and another, and the relationship between man and nature.

For this reason, a wayang performance is a source of values if it conveys an artistic or aesthetical content or message. The values contained in a wayang kulit performance are the essential values of human life, in the hope that these values can be absorbed and put into practice by the audience in their own lives, as members of the community and citizens of the state.

A study about the philosophical values contained in a wayang performance can be carried out using various different approaches, such as: by using a language of symbolism, by using an analytic-holistic method, by investigating all the ways leading to kasunyatan (truth), namely science, philosophy, religion, and art.

In addition, a study about philosophy can be carried out using a psycho-analytical approach, or by carrying out a morphological analysis, based on shape or form, according to literal imagery, so that it can be associated with a broad range of uses in a variety of cultural fields. The study of other symbolic meanings is carried out according to the archetype which originates from the subconscious. The analysis of signs in a wayang kulit performance can be divided into two parts: first, the non-visual signs, that is the signs contained in symbolism, one of which is an allegory or aphorism.

For example, the wayang screen symbolizes the world, the lamp is a symbol of the light of life, and the wayang is the symbol of God. Second, the visual signs, that is the kinds of signs and symbols that are not associated with mystical or supernatural and metaphysical beliefs.

The wayang community is inspired by the story presented in a wayang performance, and analogizes it with human character and behaviour as we strive to reach our material and spiritual goals. The understanding of this analogy is not simply by thought or reason but by using all the creativity, feelings, and desires (cipta-rasa-karsa) of a person, depending on his or her level of maturity (Ciptoprawiro, 1986:31).

The experience and total comprehension needed by man to attain true unity (ngudi kasampurnaan) is not explained directly through words but rather is embodied in analogies through the works of literature that are usually used as the source of wayang kulit stories. One of the most popular wayang stories is the story of Bimasuci or Dewaruci. This story was written by a literary scholar from the Surakarta palace by the name of Yasadipura I, and it tells the story of Bima's search for the water of life (tirta pawitra) under the guidance of Durna. Bima is ordered to travel to Candramuka mountain but when he arrives there, he encounters two ogres, Rukmuka and Rukmakala. A battle ensues and Bima fails to find what he is looking for. He returns to Durna who orders him to go to the middle of the South Sea.

After entering the sea, Bima is attacked by a huge dragon. He final meets Dewaruci, the highest god of all. In this place, Bima has a number of different experiences and sees pancamaya (five shadows), caturwarna (four colours), hastawara (eight colours), and pramana, or an ivory doll. This story describes the process of awakening of the five senses by controlling the desires of the flesh to achieve self awareness, and finally to attain divine enlightenment. For this reason, the story of Bimasuci can be said to be a philosophical mystical contemplation and the essence of Javanese mysticism, which is portrayed through this story as an explana- 
tion of mystical wisdom, to achieve the ultimate goal of manunggaling kawula Gusti (the unity of man and God).

The story of Bimasuci by Yasadipura I is used as the source for a wayang kulit story, and among puppeteers (dalang) it is known as the story of Dewaruci or Sena Meguru, or Bimasuci. Dalang in Surakarta, however, differentiate between the story of Dewaruci and the story of Bimasuci. In their opinion, the story of Dewaruci tells of Bima studying with Danghyang Durna and searching for the water of life as a means of striving to attain a perfect life, and ultimately meeting with Dewaruci.

When they meet, Bima is given advice about the origin and purpose of human life, known as sangkan paraning dumadi. The story of Bimasuci, meanwhile, tells the story of Bima after he has studied with Durna and managed to gain knowledge about the perfection of life, and wishes to put his knowledge into practice while living in the hermitage of Ngargakelasa and adopting the title Begawan Bimasuci.

The philosophy of the Indonesian archipelago is one of the traditional philosophies that has grown and developed in Indonesia. Many of the experiences and the total comprehension needed to attain a perfect life cannot be expressed through words. This fact has been recognized throughout history by the mystics of numerous nations, and this is the reason for the use of symbolism (Ciptoprawiro, 1986: 30).

If western contemplation uses a rational analysis, Javanese contemplation is carried out through meditation in the silence of creation, feeling, and desire (cipta-rasa-karsa). Indonesian or Javanese philosophy has been manifested in the art of wayang. Although the stories originate from India, there are basic differences in form. In India, it is believed that the wayang stories really happened, whether in myth, legend, or history. In Indonesia, however, the Mahabharata and Ramayana stories are an analogy of human character and behaviour in striving to attain both material and spiritual purpose in life.
The understanding of this analogy is not carried out simply through logical thought or reasoning but rather with the entire cipta-rasa-karsa of a person, depending on the level of maturity (CiptOPRAWIRO, 1986: 31).

Therefore, the study of Serat Bimasuci in a wayang performance, which is known as the story of Dewaruci, is an analogy which is highly popular and has penetrated the inner hearts and minds of those who are active in the wayang community.

What makes this story so interesting is that it tells about the search for truth or reality. This story is in truth only a tool for portraying man's struggle to attain a perfect life, both physically and spiritually, and describing the journey of a man who discovers his own character from within. When Bima enters Dewaruci's womb, he witnesses all kinds of events and he becomes aware of the true essence of man and his relationship with nature, with God, and with other human beings. Bima's endeavour to discover the perfection of life contains several philosophical aspects, including metaphysical/ontological aspects, anthropological aspects, epistemological aspects, and ethical/aesthetical aspects.

\section{METAPHYSICAL ASPECTS}

The words metaphysical and ontological are sometimes treated as having the same meaning and sometimes not. Etymologically, the word metaphysics comes from the Greek term ta meta ta physika, which means "after or beyond physical reality", while the word ontology comes from the term to on bei on. On is the neuter form of oon, with the genitive form ontos, which means "a being as being" (SuTRISNO., dkk, 2009:102).

Christian Wolff divides metaphysics into two branches, namely general metaphysics, which he calls ontology, and special metaphysics, which includes metaphysical cosmology, metaphysical anthropology, and metaphysical theology. General metaphysics (ontology) at- 
tempts to answer problems and provide a general picture about structures that exist or the true reality of all reality. Metaphysical cosmology answers questions about the universe, unlike empirical cosmology, which is based more on physics and astronomy.

In essence, metaphysical anthropology answers questions about the reality of human life, while metaphysical theology answers questions related to the concept and understanding of man in his connection with that which is transcendent (SuTRISNO., dkk, 2009:103-104).

A study of metaphysical aspects in this context takes as a starting point the existence of man and nature as a real entity that can be captured by the five senses. The aim is to discover the origin and destination of all creation, or to use the Javanese term sangkan paran (CIPTOPRAWIRO, 1986:22).

Sangkan paraning dumadi means the beginning and end of the universe. Man's search will end with wikan (knowing) and werub (understanding), or by understanding sangkean paran. Man's effort to return to his origin, or to God, is through both physical and spiritual means.

The story of Bimasuci describes Bima's search for the water of life, which really means that he has the desire to become reunited with that from which he came, to discover the secret of "existence," and to overcome that which binds him to the world. In order to attain perfection of life, Bima must find the holy water by travelling to the source of the water of life. In this event, Bima has in fact already reached the depths of reality by entering into the realm of his inner being.

He discovers that the water of life cannot be found in the physical world but inside his own being. In a wayang kulit performance, this scene portrays a small version of Bima (Bima Kecil or Bima Katik), who is referred to as Dewaruci. That Dewaruci resembles Bima is not strange, since Dewaruci is in fact Bima's own inner self. The small figure of Bima symbolizes the fact that in the beginning, one's in- ner being appears insignificant in comparison to one's physical being. Bima comes to realize that essentially, his deepest existence is of a divine nature. When inside Dewaruci's womb, Bima is in truth inside his own being.

In the beginning, Bima sees the ocean as a vast expanse of water with no shore in sight. He has no sense of orientation, and is lost in the desolate ocean where there is no sun, surrounded only by emptiness. This emptiness symbolizes the divine being, and Bima comes to realize that he comes from God. Dewaruci shows Bima a single flame with eight colours: pink, purple, green, grey, blue, yellowish red, orange, and greenish white, and explains that the single flame is the flame of the spirit.

The ray of light with eight colours is the light of blood, like a flower and its scent, its shape and colour, its form and flame (urub). Flame stands for life (urip), colour (warna) stands for screen (warana), which is really water (banyu). If we turn the words around, they become banyu urip or water of life. The eight colours are really a reflection of eight characteristics that can be found in the universe and be perceived by the five senses. These eight characteristics that exist in the universe are known as 'asthabrata', which means eight main precepts: sun, moon, stars, earth, water, sea, wind, and fire. These eight precepts represent the human characteristics of strength, beauty, stability, patience, purity, aptitude, prudence, and tranquillity (ADHIKARA, 1984:40).

So the eight colours, or asthabrata, represent the characteristics of God the Almighty that are contained in the world he created. Bima then sees an ivory doll or a golden doll, and Dewaruci explains that it is made from a substance used in three places (Triloka): a low place, a middle place, and a high place (Janaloka, Indraloka, and Guruloka). Janaloka is the home of the evil spirits, Indraloka is the home of the knights and kings, and Guruloka is the home of the holy ascetics. The little ivory doll is given the name pramana, and the body of pramana 
ensures that the life of the human body is preserved.

As long as the heart continues to beat, and as long as pramana is in the body, then a person remains alive. Pramana does not feel the happiness or sadness felt by human beings. Within a man's inner being, the essence of divine characteristics unite to form a human power known as his inner spirit or soul.

This soul gives life to the spirit, through the bearer of life (pramana). It is the soul that supports all the divine characteristics and gives life to all God's creations, remaining faithfully united and inseparable from man. The soul is the essence of the human spirit, and an expression of the divine spirit in its entirety. Bima's journey into his own inner self means that he has attained divine reality.

\section{ETHICAL ASPECTS}

Ethics is a branch of philosophy or critical and fundamental ideas or thoughts about moral principles and views. Ethics and moral principles are not on the same level. Moral principles teach us how to live, while ethics tries to understand why we should follow particular moral principles, or how we should adopt a responsible attitude towards various moral principles (Suseno, 1987:14).

Based on this understanding of moral principles and ethics, there are numerous moral principles or lessons contained in various aspects of wayang performances, such as janturan (narration), pocapan (speech), ginem (dialogue), suluk (mood songs), and tembang (sung poetry). In the story of Bimasuci, there is a moral lesson contained in the scene where Durna orders Bima to search for the water of life on Candramuka mountain.

This incident describes the attitude of a student who must trust his teacher, even though the teacher's request is not easy to carry out. Bima remains faithful to his teacher, Durna, in the real world so that he is able to avoid temp- tation and not be led astray. He gladly follows Durna's orders and travels to Candramuka to find the water of life. After digging and uncovering many rocks and stones, two terrifying ogres, Rukmuka and Rukmakala, appear and attack Bima. A fight ensues and the two ogres turn out to be reincarnations of Betara Bayu and Betara Indra.

The battle between Bima and the two ogres is the symbol of a person who is starting to meditate, making mental preparations for a spiritual journey. Durna orders Bima to continue his search for the holy water in the forest of Tibrasara in a cave in the hillside of Candramu$\mathrm{ka}$, at the foot of Gadamadana mountain.

The name Tibrasara comes from the word tibra, which means sad or troubled, and the word sara, which means arrow. Hence, Tibrasara can be taken to mean an arrow leading to sadness.

The name Candramuka comes from the word candra, which means moon or aphorism, and muka, which means face or front. Hence, Candramuka means faced with an aphorism.

The name Gadamadana comes from the word gada, which means a bludgeon or weapon used to destroy something, and madana, which means love or obsession for something.

The names of the two ogres, Rukmuka and Rukmakala, come from the word rukma, which means gold, and is a symbol of wealth. Muka means to face something and kala means to ensnare. Hence, Rukmuka and Rukmakala mean: greed which can ensnare when faced with wealth. In Adhikara's words, the battle between Bima and the two ogres can be described as follows:

"Oh Bima, what you face (muka) in this forest is an aphorism (candra), of greed (raksa$s a$ ), and obsession (madana) for wealth (ruk$m a$ ), faced (muka) by a person who finally aims (sara) and is ensnared (kala) by sadness (tibra). Therefore, he is destroyed by the weapon of greed (raksasa) inside himself 
(ADHIKARA, 1984: 17-18)."

During his journey into his inner self, Bima must pass through numerous obstacles, cleanse himself through concentration, and free himself of evil desires and improper thoughts, until he reaches his goal, to attain total comprehension of his own true teacher. When Bima enters into the womb of Dewaruci, he sees four colours: black, yellow, red, and white. Dewaruci explains that black encourages damaging deeds, anger, and greed.

It begins with the taste of earth, its place is on the forehead, and it becomes refined like a black heaven. If a person becomes trapped there, his views will be turned around and he will become a kind of slithering creature. The colour red encourages desire. It begins with the taste of animals, its place is in the gall bladder, and it becomes refined like a red heaven. If a person is trapped there, his views will be turned around and he will become a kind of crawling creature.

The colour yellow encourages aspirations and calm. It begins with the taste of the wind and the sky, its place is in the lymph, and it becomes refined like a yellow heaven. If a person is trapped there, his views will be turned around and he will become an animal that can fly. The colour white encourages a tendency to forget or carry out misdeeds, and the desire to be better than others. It begins with the taste of water, its place is in the heart, and it becomes refined like a white heaven. If a person is trapped there, his views will be turned around and he will become a fish (TrimurTi, 1979:15).

According to Adhikara, the colours red, yellow, and black are the colours of human characteristics rooted in the world, in which man has not yet learned to use his five senses properly to perceive that which God has created. Black stands for stupidity, darkness, anger, and tends to perform bad deeds. Red stands for actions led by desire and a lack of wisdom. Yellow stands for human actions which lead to destruction and obstruct the preservation of happiness.
Only white represents human behaviour which leads to purity, well-being, and true happiness. If white can counterbalance the other three colours, namely black, red, and yellow, then the four colours will disappear and human behaviour will be coloured by eight colours which represent the combination of all man's behaviour. (ADHIKARA, 1984:40).

Hence, it can be said that the four colours represent human desires, and in the story of Bimasuci, Bima has managed to control his desires. The clothes worn by Bima are known as kampuh poleng bang bintulu and also represent the four desires symbolized by the colours red, yellow, black, and white.

In Javanese culture, kampuh poleng bang bintulu, or the cloth worn by Bima, symbolizes the gathering of sedherek gangsal manunggal bayu, which means five brothers with equal strength and the same values, the five brothers representing the "character" of every person.

Four of them symbolize the characters known as: lauwamah (black), greed; amarah (red), quick-temperedness; supiab (yellow), kindness and politeness; and mutmainah (white), purity and honesty. The fifth is mayang, which shows the right direction to travel. In the philosophy of Javanese mysticism, these five brothers are known as sadherek sekawan gangsal pancer, each of which is assigned a colour: black, red, yellow, white, and green (Sastroamijoyo, 1966:53).

The four desires are always present inside people, and good desires always come face to face with bad desires. In order to reach the right or proper goal, the bad desires (lauwamah, amarah, and supiah) must be controlled and overcome by the pure desire, that it mutmainah.

Man's spiritual journey to reach total unity or integration is founded on the principle of the combination of two aspects, that is physical and spiritual aspects, which must work together in harmony to achieve good behaviour. This can only happen if a person can live in death and die in life. "Live in death" means that 
while a person is alive, he must repress or kill all desires of the flesh, while to "die in life" means that although a person has killed all desires of the flesh, he must continue to live in the world. Bima has found what he has been looking for and has gained perfect spiritual enlightenment so that his heart is pure and bright, as though he has received divine revelation from God. Bima has become totally one with God (manunggal), dead in life, and alive in death (mati sakjroning urip lan urip sakjroning mati).

This sense of unity that Bima has achieved is a mystical experience, not an experience based on observation through the five senses but rather an awakening of his sensibility. The story of Bimasuci is anthropocentric in nature, that is man is the object and centre of attention. Man is a creature with both body and spirit. To have a spirit means to have a soul, and man's soul is a creature that can think (homo sapiens), meaning he possesses an awareness to reason, feel, create, and desire. Man always questions, always searches, and always wishes to know himself, and at some point in time he wishes to be joined to his Maker.

Spiritual awareness is a reality that is revealed in speculation of the macrocosm (jagad gedhe) and microcosm (jagad cilik).in Javanese mysticism, the macrocosm means the real world, while the microcosm means the human body.

If a person can find inner balance by controlling physical aspects, he will become a knight who is also a spiritual teacher (ksatria pinandhita), and by obtaining a deep understanding of his own spirit, he will become one with God. God here is understood as a transcendent and imminent being. An entity whose form cannot be described, without colour, without shape, without offspring, neither male nor female, and intangible. It can be said that God is an unknown being (datan kena kinaya ngapa), God is an empty space (awang-uwung). The soul is the essence of a living substance and can be interpreted as the essence of God's own nature that is supported by the human spirit, while man's spirit is supported by his soul. A perfect human being is one who is aware of his origins, who knows himself, and who makes God real within himself. The characteristics of God that are found in His creations can only be attained by a man who has reached a state of perfection.

\section{EPISTEMOLOGICAL ASPECTS}

According to Randall and Buchler in Sutrisno, epistemology is the branch of philosophy which focuses on the main problem of the meaning and purpose of human experiences that are more than just knowledge (SUTRISNO, 2009:49).

Meanwhile, Trtus, also in Sutrisno, states that epistemology is the branch of philosophy concerned with the sources, nature, and validity of knowledge. Veuger defines epistemology as a study of philosophy which considers, explains, and justifies knowledge in general. Halmyn, on the other hand, states that epistemology is the branch of philosophy concerned with the truth and range of basic knowledge (SUTRISNO, 2009:49)

Based on the thoughts and ideas of these philosophers, truth is the goal of everything we know. The value of truth depends on the accuracy of our perception of an object so that vitality and truth are not measured by objective norms. In wayang stories, we encounter a lot of knowledge whose truth needs to be tested, in the hope that if we find the truth of this knowledge, it will increase the degree of certainty and ultimately the level of conviction.

For example, knowledge may be passed on through the senses, through the mind, through intuition, or through divine revelation. In Indonesian philosophy there is also a similar way for acquiring knowledge, through the stages of creating, feeling, desiring (cipta-rasa-karsa), with the following levels: awareness of the senses or ego consciousness; silent awareness, united in creation, feeling, and desire; personal awareness or self consciousness; and awareness 
of the divine (CiptopraWiro, 1986:24).

In the story of Bimasuci, Bima succeeds in finding the holy water of life. This event describes the process of gaining knowledge by using human abilities in the form of creation feeling and desire, through different levels of awareness: awareness of the senses, silent awareness, personal awareness, and divine awareness. Bima has heard and understood all of Dewaruci's advice, he knows about the origins of his existence, and is aware of the union between man and God. By becoming united with God, Bima gains knowledge from Dewaruci (The Real Teacher), unconditional knowledge about the origin of human life.

The preparations and mental training that Bima has undergone are with the aim of showing his "feelings," so that reality is captured by his feelings and disclosed within his spirit. In these feelings, his ego has become one with God. In this condition, there has occurred a union between God and all that has been created by man and God. At this stage in the story, Bima is described as entering into the body of Dewaruci (to become one). Then, Bima is given advice by Dewaruci. He is told about the knowledge of letting go, that is letting go of the body and soul. There is also an explanation about the guidelines by which a person should live if he or she wants to learn better behaviour and become united with God, namely to die in life and to live in death. If a person can control or kill all his desires, he will become one with God (manunggaling kawula Gusti) in a mystical union. In this story, Bima has reached a level of makrifat (the highest knowledge in which he can see God), and has achieved perfection of life and gained the knowledge about the origin and purpose of life (sangkan paraning dumadi).

After returning to the world, Bima realizes that he is still on earth where man lives, but he has discovered himself, has learned about perfection, and will carry out his obligations in the world, that is to guard and keep safe the world. Bima's actions are based on a strong de- termination supported by eminent conduct to achieve a state of unity with the Maker.

This principle is a moral obligation and the main goal of practising Javanese mysticism or spiritualism. In Javanese spiritualism, in order to obtain a mystic experience, a person must first pass through a number of stages, namely sarengat (the prescriptions of Islamic law), tarekat (the path for mystics to follow), hakikat (truth or reality), and makrifat (the highest knowledge in which a person can see God). During Bima's journey to reach a union with God, he must also pass through the same stages as in Javanese mysticism.

When Bima meets his True Teacher, he witnesses various events, and here he sees the essence of man in his relationship with God. He sees five shadows, a picture of the universe as it is perceived by the five senses and recorded in a person's inner mind as a life experience. These five shadows symbolize the five senses. Next, Bima sees four colours: red, yellow, black, and white, which symbolize human desires. In the next instance, he sees eight colours, which are a reflection of the eight characters found in the universe.

These eight colours represent the microcosm and macrocosm, and in Javanese culture are known as hastha brata. Bima's journey to reach these eight colours in the story of Bimasuci constitutes a cosmic understanding. Bima and Dewaruci symbolize the "ego" and the essential power of the divine being, while the eight colours symbolize the power of the universe which is the numinous essence of the human ego. The hastha brata contained in the story of Bimasuci, and also in the story Wahyu Makutharama essentially present a lesson in leadership for both those in power and society in general.

During the New Order government, hastha brata was a doctrine used in the management of government institutions and also a directive for motivating the community. The doctrine hastha brata is explained in more detail 
below:

1. Hambeging Surya (the character of the sun). The sun gives out heat and light and is the source of life that enables all living creatures to live and grow. A leader must have the ability to stimulate the growth and development of his people, continually giving life and courage to them all.

2. Hambeging Candra (the character of the moon). The moon provides light in the darkness of the night. This means that a leader must be able to give comfort and provide spirit and hope for his people in times of joy and sorrow, and provide light in the darkness.

3. Hambeging Kartika (the character of the stars). The stars radiate beautiful bright light, and from their place in the sky can act as a compass. A leader must set an example for his people by doing good, so that he becomes a point of orientation and a guide for them all to follow.

4. Hambeging Hima (the character of the clouds). Thick cloud produces rain. This means that a leader must have authority and his actions must provide prosperity for his people.

5. Hambeging Samirana (the character of the wind). Wind can travel anywhere without distinguishing between one place and another, filling empty spaces. This means that a leader should be close to his people and his policies should be favourable for all his people so that his leadership can be appreciated by all levels of society.

6. Hambeging Samodra (the character of water or the sea). The sea is a vast expanse of water with unimaginable power. A leader must have a strong vision, be honest, be able to accept criticism, be fair, and be able to offer solutions to difficulties encountered by his people.

7. Hambeging Dahana (the character of fire). Fire has the power to burn and destroy all that it touches. A leader must have the courage to enforce justice and truth without discrimination, and solve all problems that occur.

8. Hambeging Bantala (the character of the earth). The earth is strong and generous. This means that a leader must be humble, be able to put himself in another's place, be honest, expect no reward for his actions, and give rewards to others who do good.

Wayang kulit performances often contain local wisdom about lessons of leadership, taken from various literary sources such as: Wulangreh, Wedatama, Tripama, and so on. One of the lessons about leadership is contained in the work Serat Wulangreh by PAKU Buwana IV and reads as follows:

1. “Aja nedya katempelan,ing wewatek kang tan pantes ing budi. Watek rusuh nora urus, tunggal lawan manungsa, dipun sami karya labuhan kanga patut, darapon dadi tinuta ing wuri-wuri”.

2. "Aja lonyo lemer genjah, angrong pasanakan nyumur gumuling, ambuntut arit puniku, watekan tan raharja, pan wong lonyo nora kena dipun etut, monyar-manyir tan antepan dene lemeran puniki”.

3. "Para penginan tegesnya, genjah iku cecegan barang kardi, angrong pasanakan liripin, remen salah miruda, mring rabine sadulur miwah ing batur, miwah sanak myang pasanakan, sok senenga den ramuhi”.

4. "Nyumur gumuling tegesnya, ambelawah datan duwe wewadi nora kena rubung-rubung, wewadine kang wutah, buntut arit punika precekanipun abener ing pangrepe nanging garathel ing wuri”.

The lesson about leadership contained in the words of Pangkur essentially states that there are six things a leader must avoid: aja lonyo, aja lemeran, aja genjah, aja angrong pasanakan, aja nyumur gumuling and ambuntut arit. Aja lonyo means that a leader should not be hesitant when making a decision; aja lemeran means that a leader 
should not easily succumb to all his desires as it will lead to extravagance; aja genjah means that a leader must work hard and be responsible for all his actions; aja angrong pasanakan means that a leader must not disturb another man's wife or have an extra-marital affair; aja nyumur gumuling means that a leader must be able to keep a secret; and ambuntut arit means that a leader must have noble qualities.

Another example of local wisdom that is also often presented in wayang kulit performances in scenes containing a priest and a knight is known as Panca Pratama (the five best qualities that a leader should have): mulat, amilala, amiluta, miladarma and parimarma. Panca Pratama is taken from the literary work Serat Witaradya which was written by RANGGAWARSITA, a literary scholar who resided in the Surakarta palace from the reign of PAKU BUWANA VII to Paku Buwana IX.

The meaning of Panca Pratama is: (1) mulat (to be cautious or careful), which means that a leader must understand the capabilities of his subjects and be cautious of both those who are good and those who are evil; (2) amilala (to look after or to pamper), which means that a leader must be able to give appreciation to those who do good deeds or those with accomplishments; (3) amiluta (to persuade or coax), which means that a leader must be able to approach his subjects with words of comfort, and provoke a sense of respect and love for their leader and their country; (4) miladarma (to wish for wisdom), which means that a leader must be able to give enlightenment and teach his people how to attain spiritual fulfilment, and also honour his people; (5) parimarma (to have pity or compassion), which means that a leader must have a strong sense of humanity and the ability to forgive.

Another lesson about leadership which is often presented in certain scenes of a wayang kulit performance is about the concept of Olah Praja (public management) and Tata Praja (public administration), as quoted from the work
Serat Narapati Tama, written by PAKU Alam I, which states that a good leader is one who has the following qualities: wikan-wasitha, wicaksanengnaya, mengku ning uga ngayomi, wening nguri budaya, wenang ngluberi, and waskitha prana.

This means that a good leader is one who has the following qualities: (1) wikan, or the skill to master government concepts and doctrines about politics and security; (2) wicaksanengnaya, which means the ability to develop and apply his sense of authority to all corners of the world; (3) mengku ning uga ngayomi, which means the ability to master all the ins and outs of his duties as a leader while at the same time protecting his people; (4) wening nguri budaya, wenang ngluberi, which means the ability to support and develop his culture and to delegate his power and share his wealth, and also the ability to choose and decide what is important, while maintaining peace and spiritual stability and trying to make the world a more beautiful place (berbudi bawa leksana, anbeg darma, memayu hayuning bawana). In addition a leader must also be able to protect and shelter his people and to increase their dignity and standard of living (ngrungkebi kumrembyabing ngagesang); and (5) waskitha prana, which means the ability to look far into the future and to have knowledge and wisdom.

In the Gara-gara scene of a wayang performance, which presents the characters of Semar, Gareng, Petruk, and Bagong, there are also often lessons about leadership which are presented in a comic fashion or through sung poetry (tembang macapat). For example, Petruk may sing tembang Sinom from Serat Wedhatama by Sri Mangkunegara IV (1853-1881), which reads as follows:
"Bonggan kang tan mrelokena, mungguh ugering ngaurip, uripe lan tri prakara, wirya, arta, tri winasis, kalamun kongsi sepi, saka wilangan tetelu, 
telas-telasing janma,

aji godhong jati aking,

temah papa papariman ngulandara ".

(If a person does not pay attention to the basic needs of life,

that is three basic needs, work (status), money, and intelligence,

if a person does not have these three things,

he will lose his status as a human being,

a dried teak leaf will have more worth than such a person).

One of the characters who often presents local wisdom in a wayang kulit performance is Semar. For example, he may say that a leader must stand in front to give an example and give motivation, and stand behind to give moral support and material support (ing ngarsa sung tuladha, ing madya mangun karsa, tut wuri handayani). This lesson comes from the cultural expert, R.M.SASRAKARTANA, and one of Indonesia's educational leaders, Ki Hajar Dewantara.

Another lesson is Tri Dharma: melu handarbeni, melu hangrungkebi, mulat sarira angrasa wani (to own, to preserve, and to always carry out self-correction through introspection), which is a value of nationalism that a leader must possess. The Tri Dharma doctrine, which is a form of advice, motivation, and also a message, is taken from a work by MANGKUNEGARA I or RM. SAID who ruled in the Mangkuegaran Palace from 1757-1795 AD.

Other Javanese expressions conveyed in the world of wayang performances include: nglurug tanpa bala, menang tanpa ngasorake, digdaya tanpa aji, sugih tanpa bandha; nglurug tanpa bala, tanpa gaman, ambedhah tanpa perang, tanpa pedhang, menang tanpa mejabi, tanpa nyakiti, menang tanpa ngrusak ayu, tan ngrusak adil, yen unggul sujud bekti marang sesami. Broadly speaking, these expressions mean that a leader must be skilled at diplomacy, able to conquer his political enemies in such a way that they are unaware, and always give priority to humanitarianism and a sense of family. Wayang scenes which present holy men such as Abiyasa who is confronted by Abimanyu also contain advice in the form of euphemisms, such as: leladi sasaming dumadi, memayu hayuning sesami, leladi sesamining umat, mamayu hayuning jagad, ngawula dhateng kawulaning Gusti, mamayu bayuning urip, which means that a leader must have a noble character and always carry out his duties as a public servant, by serving his people and not by being served, always try to make the world more beautiful, and always remain reverent in his actions.

Other lessons about leadership that are contained or implied in wayang performances include lessons on moral behaviour, which state that a leader must be loving and caring, have a deep sense of humanitarianism, be just, be able to accept constructive criticism, and always be able to adapt to different situations and conditions (asih mring sesami, adil paramarta, sabar, momomg, momor, momot).

The following expression has become the basic principle for leadership in the headquarters of the Indonesian National Army : "Taqwa, ing ngarsa sung tuladha, ing madya mangun karsa, tut wuri handayani, waspada purba wisesa, ambeg para marta, prasaja, satya, gemi nastiti, blaka,dan legawa", which means "Be reverent, give an example from the front, give encouragement from the middle, and protect from behind, always act carefully, be wise, honest, loyal, not extravagant, down to earth, and kind-hearted.

The leadership values that are contained in hastha brata and panca pratama, and written in ancient literary works, are still relevant today. If we compare the local wisdom of Indonesia with western management systems, they are essentially the same in that they promote truth and wisdom. In the west, truth is sought through logic and reason, while in the east, or in Indonesia, it is sought through contemplation or meditation.

Therefore, a wayang performance should not only be viewed by its visual aspects 
but also by the religious and cultural aspects contained therein, which can be used to solve many of life's problems. Advances in technology and information have influenced people's lives and dragged them in the direction of pragmatism, materialism, hedonism, and meaninglessness. For this reason, it is hoped that art or wayang performances can help to balance people's lives against economic advances, which in turn will improve the quality of people's lives. It is hoped that by understanding and appreciating the values contained in wayang performances, people will develop attitudes of respect, tolerance, harmony, peace, and courtesy in a multicultural society.

\section{MYSTICISM IN THE STORY BIMASUCI}

\section{MYSTICISM}

The term mysticism comes from the Greek word "muo" which means to cover the face or shut the mouth, to conceal. Hence, mystical means something that is hidden or contains a secret (SurAHARDJO, 1983:1). The word mystical has been around since pre-Christian times, such as in the mystery of religion where mysticism was a secret ritual. Since the birth of Christ, the term mystic has been used to interpret allegorical meanings in deep, abstract, complex and theologically problematic Christian teachings through mystical interpretations.

In subsequent developments, the term mystical more often refers to spiritual reality, that is total spiritual comprehension which is intimate and full of emotion in the existence of absolute reality which is full of secrets (mystical union). In the west, during the era that came next, the term mystical took on a number of different connotations, depending on who was responsible for defining the term (SURAHARDJO, 1983: 1-2).

Javanese mysticism is generally know as kebatinan. The word kebatinan comes from an
Arabic word which means inside, essence, internal, in the heart, hidden, and mysterious. The practice of kebatinan is an attempt to communicate with the origins of reality, and as a branch of knowledge, kebatinan studies the place of human beings in the world and in the cosmos, based on the belief of a true union between all that exists (Mulder, 1983:22). A person who practices kebatinan must follow a lonely and dangerous path which will lead him or her to the discovery and comprehension of the highest form of reality. According to Djojodiguno, kebatinan can be divided into four categories, as follows:

1. Those who place importance on ethics and morality, and in their day to day ;

2. Lives always avoid bad or evil words and deeds, have complete trust in God, accepting and acquiescing to all that $\mathrm{He}$ has given them and putting it to the best possible use;

3. Those who place importance on metaphysical aspects, based on philosophical thoughts and beliefs about the universe and themselves;

4. Those who place importance on occultism or use special powers either on themselves or on their surroundings, such as to cure disease, to predict the future, and to help others. On the contrary, people who use these special powers to do evil, such as by meditating, casting magic spells, making people sick or by mediumship, are also included in this category;

5. Those who place importance on creating a union with their place of origin, or who attempt to be reunited with God. These people are called mystics (unio mystica $=$ mystical union). When hearing that someone has died, a Moslem will say "Inna Lilabi wa inna Illaibi roji'un" (from God we come and to Him we return). Mystics or followers of Sufism try to unite with their God while they are still alive so that they have prior experience before they die (TrimurTi, 1979:12). 
Kebatinan may also be defined as a spiritual path, which in its development has come to include two types, outlined as follows:

1. Human behaviour which aims to discover the origin of life, perfection, truth, or God. This behaviour is universal and has developed in all religions, and is known as mysticism and the esoteric path. Hinduism has yoga, Buddhism has samad (blessings bestowed by magical powers), Taoism has meditation, Judaism has kabbalah, Christianity has mysticism, Islam has mysticism or Sufism, and Indonesia has a special form of mysticism known as suluk.

2. Human behaviour which attempts to make a connection with spirits or supernatural beings, which is usually known as supernaturalism or spiritualism. This also often includes kanuragan, the development of supernatural powers which are potentially found inside every person. These powers are now also referred to as paranormal powers (ABDullah 1988:72).

The goal of Javanese mysticism is to achieve unity between man and God. Through this true unity, man gains knowledge (kawrub) of his origins (sangkan) and the goals (paran) of all that has been created (dumadi).

This mystical journey passes through four stages, beginning from the outside and travelling inward, as follows:

\section{Sarengat:}

This is the lowest stage of mysticism, respecting and living according to one's religion; controlling one's desires, learning how to treat others and how to treat all that can be found in this world; carrying out one's obligations seriously, respecting and honouring one's parents, teachers, and the king, in the awareness that by honouring them we are honouring God.

\section{Tarekat:}

This is the stage in which a person leaves behind the worldly and seeks that which is more spiritual or mystical. The essence of the behaviour in the first stage must be better understood and improved. Noble and sacred efforts are made and the basic spiritual and physical preparations are carried out in anticipation of meeting God.

\section{Hakekat:}

This is the stage for facing the truth, the stage for developing to the full one's awareness of the essence of prayer and of how to serve God, gaining a deep understanding that the only way for anything to exist is to become a servant of God, to become a part of all that depends on the whole cosmos. Regular prayers begin to lose importance because the entire life and actions of a person are a single continuous prayer devoted to God. Differences between one religion and another are no longer significant and behaviour becomes instantaneous.

\section{Makrifat:}

This is the final and highest stage in which man becomes one with God jumbubing kawula lan gusti). In this stage, a person's spirit becomes integrated with the spirit of the universe and all of a persons actions are devoted to God. A person's life is one continuous prayer, whether he is working, meditating, sleeping, or eating. At this stage, a person will shine, like the light of the full moon lighting up the earth, and through his presence, others will gain inspiration to become God's representatives in this world (Mulder, 1983 : 25).

In Wirit Hidayat Jati, which teaches knowledge of makrifat (the highest level of knowledge in which a person can see and become one with God) for a perfect life, it states that Islamic teachings have four levels: syariat, tariqat, haqiqat, and makrifat, to distinguish the level of a person's spiritual and physical devoutness. A person's devoutness, or spiritual journey, which in the history of the Islamic culture is known as Tasawuf or Sufism, is known in Indo- 
nesia as Ilmu Suluk.

The four levels stated above are understood and experienced through physical devotion (lakuning badan), devotion of the heart or mind (lakuning ati), spiritual devotion (lakuning nyawa), and devotion of the senses (lakuning rasa), through four stages or levels: main-meneng, tabid ening, makrifat-awas, and Islamic awareness.

The ultimate goal of devotion is to reach God, or to understand the beginning and end of life (waskita ing sampurnaning sangkan paran). The journey towards God is undertaken by applying the knowledge of makrifat, by understanding the essence of the divine being, learning how to reach the final destination through moral behaviour and meditation (CIPTOPRAWIRO, 1986: 73-74).

In the Moslem religion, tasawuf is the study of matters pertaining to the divinity and its connection with a human desire that is encouraged by a love of God and always strives to become closer to Him by searching for a direct connection and following a holy path. This knowledge is known as Ilmu at-tasawuf. Human life is compared to a journey, and the search for God is described as a person on a journey (known as salik). The goal of salik is to gain perfect knowledge so that man's soul can be reunited with its origins in God. This journey must pass through four stages of life: syariat, tariqat, haqiqat and ma 'rifat (1971:9).

According to Mangkunagara VII in his book entitled On the Wayang kulit (purwa) and its Symbolic and Mystical Elements, translated by Claire Holt, the role of the mystical processes can be described as four kinds of meditation, as follows:

1. Meditation to reach temporary goals of a destructive nature through black magic or witchcraft;

2. Meditation to gain great power or strength in order to achieve positive goals;

3. Meditation to discover the secret of Existence;
4. Meditation to free oneself of all worldly desires (Mangkunegara VII, 1957:13-18).

The first stage can be carried out through contemplation and meditation to achieve worldly or magical goals that can even lead to the destruction of others, with the aim of seeking profit or reward. This kind of mysticism is generally regarded as a sin as it disturbs the structure of the cosmos. It is often referred to as black magic and is likely to lead to bad consequences for the person responsible.

The second kind of meditation is to achieve positive goals, despite being encouraged by a desire for profit or reward. There are different opinions about whether or not this type of meditation should be allowed. In the past, this kind of white magic was used by kings and political leaders for the purpose of making the world better, in which case it is still permitted. The third and fourth kinds of meditation are used for the right kinds of spiritual or mystical purposes and are related to the stages of hakekat and makrifat consecutively. That is, meditation encouraged by a desire to "hear the aura of the divine being" or a "quiet voice" that aims to gain a divine revelation from the highest being and requires continual self-cleansing of the mind and the body through moral conduct and attitudes. The successful practice of this kind of meditation is considered beneficial for society and has the power to destroy evil powers and egoism while at the same time spreading justice and prosperity (Mulder, 1983: 25-26).

Kebatinan is essentially a "school" for individuals to learn how to undertake a mystical journey. In all its different variations, kebatinan is a spiritual human culture which helps to calm the spirit and senses. In order to achieve this sense of calm, a person must surrender him or herself. In the instance of surrender, a person's inner self will intuitively experience the presence of God. This mystical union is essentially free to flow in any direction, and it is initiated by "another party". What a person is seeking depends on his preparations and process of 
self-cleansing.

The practice of kebatinan is the manifestation of the views of Javanese mysticism in which the structural coordination of events or truth becomes the "cause" of those events. Man must play the role of a specified creature but in a deeper analysis, he must be present as the holder of the key to his own freedom. The practice of mysticism uses a style of reasoning which emphasizes the use of "feeling" to discover direct knowledge, in which events and experiences are explained through principles of harmony and coordination in the unity of life.

This unity is described as a hierarchy of all physical and spiritual aspects, in which the physical aspects are connected with material objects, while spiritual aspects are connected with intuition and calm. The aim of kebatinan is to develop these spiritual aspects (MULDER, 1983: 38).

Based on the above explanation, we can conclude that mysticism is the teaching of hidden secrets that are present in all religions and involves a spiritual journey to discover God the Almighty. In other words, it is knowledge which teaches a person how to become united with God. Javanese mysticism is also called kebatinan.

The practice of Javanese kebatinan is also called kebatinan. The practice of Javanese kebatinan is a personal effort to attain unity with God. In order to gain a complete understanding of mysticism and achieve a union with God, a person must pass through four stages: sarengat, tarekat, hakikat and makrifat.

Tasawuf or sufism is a term which in Indonesian mysticism is known as suluk. In order to distinguish between levels of physical and spiritual devoutness in the Islamic religion, there are also four levels, known as syariat, tariqat, haqiqat and makrifat. In Islam, tasawuf is the study of matters pertaining to the divinity and its connection with a human desire that is encouraged by a love of God and always strives to become closer to Him by searching for a di- rect connection and following a holy path.

Kebatinan is essentially a human culture which helps to calm the spirit and senses and can be achieved through a mystical method, that is by surrendering oneself, and in the instance of surrender, a person's inner self will intuitively experience the presence of God.

\section{THE STORY OF BIMASUCI AS AN EXPRESSION OF JAVANESE MYSTICISM}

During the 18th and 19th centuries, literary scholars in the Surakarta palace wrote many literary works which contain, either implicit or stated directly, teachings about Javanese mysticism, one of which is the work of Javanese sung poetry by Yasadipura I entitled Bimasuci.

The story of Bimasuci describes the journey of man to discover his own self at the beginning of his mystical journey. This mystical journey is the personal endeavour of Bima (who represents man) to uncover the secret of "Existence" and to discover the true essence of life.

Before discussing the expression of mysticism in the story of Bimasuci, first I will quote a number of opinions about the values contained in this work and also the goal of the writer (YASADIPURA I) in writing the work Serat Bimasuci. The goal of the writer was to share his knowledge about philosophy and religion, as is reflected in the first verse of his work, as follows:

\section{"Niban ndoning ulun manurat Sri}

Mring mamrih mamardawa

Tyas wigena panjutane

Juwet silarjeng tuwuh

Wabananing kahanan jati

Sujana para marta, witaning tumuwub

Minangun ingkeang sasmita ginupita ing kawi reb Bimasuci 


\section{Winangun lawan jarwa"}

My aim is to emulate the noble men who usually give beneficial advice, encouraged by a great desire to give information about the journey towards a perfect life which leads to the conclusion of true life, where such information is possessed by literary scholars with high aspirations. The purpose of this life journey is to leave behind the ordinary life. I present my information in the form of a story filled with symbolism (an omen), in a Javanese poem by the name of Bimasuci (AbDulLah, 1971: 9).

The essence of this story as presented in a wayang scene is the mystical journey of a man who wishes to be guided to reach a true understanding of the meaning of life's origins, and must meditate in order to do so. Meditation (semed $\imath$ ) in institutional language is known as patrap. In the story of Bimasuci, this noble goal is portrayed by the character of Bima in his search for the water of life (MANGKUNEGARA VII, 1933 : 89-95).

According to Poerbatjaraka, the story of Dewaruci is still believed to contain a lesson about the knowledge of perfection or liberation, and Javanese people consider it to be a book about the knowledge of perfection. This clearly means mysticism (Poerbatjaraka, 1940 : 3-6). SoEBARDi in his book entitled The Book of Cabolek states that the mystical content in the story of Dewaruci has a higher and more ethical meaning and has the effect of improving the spiritual lives of Javanese people. The character of Bima portrays a mystic with a high level of skill. After meditating and living as an ascetic, he finally reaches the ultimate goal of man, the "water of life" (SOEBARDI, 1975 : 45-50).

P. ZoetMulder, in the magazine Djawa, states that in his search for the water of life, the popular figure of Werkudara (another name for Bima) gains guidance and true knowledge, which is not rooted in the lives of the Javanese people. Indeed, spiritual life is the foundation which forms the essence of Javanese culture (Abdullah, 1986:11).
Based on the opinions of MANGKUNEGara, Purbatjaraka, Zoetmulder, and SoebarDI, the story of Bimasuci or Dewaruci symbolizes man's union with God through the water of life. The journey to find the water of life is through moral conduct, isolating oneself from the world, and meditation. In the meditative state, man gains profound knowledge and understanding which enables him to become one with God.

This true unity is expressed in several of the verses of Bimasuci. The essence of Javanese mysticism is found in some of the words of the sung poetry, as follows:

"Sirna patang prakara na malih, urip siji wewolu kang warna, sang Wrekudara ature; punapa namanipun urup 5iji wolu kang warni, pundi ingkang sanyata, rupa kang satubu, wonten kadi retna, wonten kadi maya maya angeboti wonten abramarkata. Marbudyengrat Dewaruci angling, ¿iya iki kajatening tunggal, saliring tegese 'iya na ing sireku, towin iya isining bumi, ginambar angganira lawan jagad agung, jagad cilik tan prabeda, purna ana lor kidul kulon puniki wetan ing dhuwur ngandap. Miwah abang ireng kuning putih, iya panguripe ing bawana jagad cilik jagad gedhe; pan padha isinipun tinimbangaken ing sira iki, yen ilang warnaning kang jagad kabeh iku saliring reka tan ana, kinimpulaken aneng rupa kang sawiji tan kakung tan wanadya. Kadya tawon gumana puniki kang asawang putran-putran denta, lan payo dulunen kowe. Wrekudara andulu ingkang kadya peputran gadbing, caya muncar kumilat, tumeja nggenggunung, punapa inggih punapa, warnaning Drat kang pinrih dipun ulati kang sajatining rupa.

Anuri aris Dewaruci iku dudu ingkang sira sedya kang mumpuni ambek kabeh, tan kena sira dulu tanpa rupa datanpa kalimeku kang ginambar, wus kaasta sanalika aywa lali, ulun tubu ambekna.

Warni tan gatra tan satmata, iya tanpa dunung mung durnunung mring kang awas, mung sasmita aneng ing jagad ngebeki, dinumuk datan ana. Dene iku kang sira tingali kang asawang pepu- 
tran, mutyara, ingkang kumilat cabyane, angkara-angkara murub, pan pramana arane 'nenggih, uripe 'kang sarira Pramana puniku, tunggal ane ing ing sarira, nagging datan milu sungkawa prihatin, enggone'ane 'ng raga

Datan milu mangan turu nenggih, iya nora milu lara lapa, ye 'n iku pisah enggone; raga kari ngalumpruk, yekti lungkerah badan sirerki, ya iku dening suksma, iya iku sinungsib anandhang urip, ingaken rabsaning Drat".

Translation:

The four colours disappear and another light appears with eight colours. Werkudara asks about the meaning of the light with eight colours, what is real, what really exists like a radiant jewel, some shine dimly and others burn brightly.

Dewaruci says that in essence, all that exists in the world is as one, all the colours are inside yourself, all the earth is drawn on you, and there is no difference between the macrocosm and the microcosm, the beginning and the end, north and south, west and east, or top and bottom.

The colours red, black, yellow, and white represent life in the world, the microcosm and macrocosm and all that they hold are contained and depicted inside Bima. If the world disappears, its contents no longer exist, they are all gathered together in a single form, neither male nor female, like a tiny bee, like an ivory doll, radiating light, shining brightly, giving off the colour of the Entity whose true form is unknown.

Dewaruci answers lovingly that this is not what Bima is seeking, that the one who has power over all cannot be seen, is without colour and without form, cannot be touched. That which the eyes can see has no place and is only found in those who have gained a true understanding, it is only an omen which fills the world but cannot be touched.

What you see, that which appears to shine like a pearl doll, glowing and burning bright, is called Pramana. The life of Pramana becomes one within but feels no joy or sorrow, its place is in the body.

It neither eats nor drinks, feels no cause for trouble if it loses its place and man meets his end. How weak is your body. That is The Almighty God, who can feel, who is kept alive by the soul, who gives life, and who is known as the mysterious being.

These few verses from Serat Dewaruci explain Dewaruci's advice to Werkudara and are the essence of Javanese mysticism as contained in the story of Bimasuci. Dewaruci's advice about the four colours, black, red, yellow, and white, is that they represent human characteristics. Pramana is the one who keeps life in balance, the soul. The text also explains about God's immanence in the large world (the universe and macrocosm) and the small world (the microcosm), between which there is no difference.

Man, the universe, and God are a single entity in which all communicate with each other. The union between man and the universe represents the unity of the macrocosm (the physical world) and the microcosm (the spiritual world). Man is always in communication with God. The unity of the measureless universe is achieved by the interconnection of all the units within. The unity experienced by Bima can be achieved because of his moral conduct to cleanse both body and soul until he gradually reaches a level of spiritual awareness and feels himself to be inside a place without limits and attains a sense of sublime unity. Bima's unity with Dewaruci can be referred to as curiga manjing warangka, warangka manjing curiga, which means that the keris is one with its sheath and the keris's sheath is one with the keris itself. The keris represents the nature of God and the sheath represents man. Manjing means united. Hence, the meaning of the above expression is that the nature of God is united with man and man is united with God. 
The knowledge Bima gains that enables him to become one with God is a mystical experience, not an experience from his five senses but from his sensory perception. The next part of the text compares the teachings of Javanese mysticism with the teachings of the mysticism contained in the story of Bimasuci. The story of Bimasuci is anthropocentric. Man becomes the object and centre of attention. Man is a creature with both body and spirit. His spirit is his soul, and a creature with a soul is one who can think (Homo sapiens), so a human being has the ability to reason, feel, create, and desire. Man always asks questions, always searches for answers and is constantly searching for himself until he reaches a point where he wishes to become one with his Maker.

Spiritual awareness is the reality that is revealed in speculation of the macrocosm (jagad gedhe) and microcosm (jagad cilik). In Javanese mysticism, the macrocosm symbolizes the physical world while the microcosm symbolizes the human body. If man can find a spiritual balance by controlling his physical desires, he will become a person of noble qualities and at the same time a spiritual teacher (ksatria pinandita). By entering into the depths of his own soul he will become one with God.

In this instance God is understood to be a transcendent and immanent being, an unknown entity, without colour, without form, without offspring, neither male nor female, and intangible. God is datan kena kinaya napa (an unknown being), an empty space. The soul is the essence of a living substance, and can be interpreted as the essence of God's own nature that is supported by the human spirit, and vice versa, man's spirit is supported by his soul.

A perfect human being is one who is aware of his origins, who knows himself, and who makes God real within himself. The characteristics of God that are found in His creations can only be attained by a man who has reached perfection.

In Javanese mysticism or kebatinan, it has been stated that in order to undergo a mystical experience, a person must pass through the stages of sarengat, tarekat, hakekat, and makrifat. Bima's mystical journey to reach a union with God also passes through a number of stages similar to those in Javanese kebatinan (sarengat, tarekat, hakekat and makrifat). In sarengat, a person learns how to control his desires, how to treat his fellow human beings, and how to treat all that exists in this world. In this stage, Bima has the determination and courage to confront death and is willing to follow whatever his teacher orders him to do with the same sense of determination, due to his faithfulness. Bima's mental preparations include controlling his greed and other desires of the flesh. This is depicted through Bima's battle against the two ogres, Rukmuka and Rukmakala.

In the tarekat stage, if a person has already learned how to lead a clean life, he is now required to think about the "path" he should take to lead him towards his ultimate goal. He must develop his experiences in the spiritual world until he meets and becomes one with God. In this stage, Bima is described as entering into the middle of the ocean and coming face to face with a dragon which attacks him but is then killed by Bima. In his exhausted state, allows himself to be carried along by the waves until he falls unconscious. This symbolizes that Bima has broken free from all worldly ties.

In the hakekat stage, Bima meets Dewaruci who appears in the form of a small child (lare bajang or Bima Katik) who is none other than Bima himself in his deepest existence which is of a divine nature. Here, Bima meets his true teacher and then witnesses several events. He sees the essence of man in his relationship with other human beings, with nature, and with God as follows:

1. Pancamaya (five shadows), a picture of the universe as it is perceived by the five senses and recorded in a person's inner mind as a life experience. These five shadows symbolize the five senses. 
2. Catur warna (four colours), black, red, yellow, and white, which colour human behaviour These four colours symbolize human desires.

3. Hastawarna (eight colours), a reflection of the eight characters found in the universe that can be perceived by the senses and stored as five shadows in the human mind and heart. Hence, there is no difference between the universe and the small world, or the five shadows that are kept in man's heart and mind. The eight colours symbolize the unity of the macrocosm and microcosm.

4. Sang Pramana is the Holy Spirit which gives life to the human body, and whose true place and concern is to protect the balance of human life, the soul. This stage also explains God's immanence, the divine nature of all that He has created in the universe, or macrocosm, and microcosm, between which there is no difference.

In the makrifat stage, man will experience or gain justification through his service to God the Almighty. He will become aware of his union with God. In this stage, Bima is described as entering the body of Dewaruci (becoming one).

Bima is then given advice by Dewaruci about the knowledge of liberation, about how to break free from the soul and the body. It also describes the guidelines that a person should follow if he wishes to improve his moral conduct and become one with God, that is to die in life and to live in death (mati sajroning ngaurip).

To live in death means that while a person is still living in this world, he must control his desires, while to die in life means that although a person has controlled his desires, he must continue to live in the world. If a person can overcome all his desires, he will become one with God in a mystical union. In this case, Bima manages to reach the stage of makrifat by achieving a perfect life and discovering the origins and goals of life.
Bima then returns to the universe and realizes that he must continue to live on earth with other human beings. He knows his own self and has attained perfect knowledge, and will carry out his good work on earth by protecting and keeping safe the world. Bima's determination is supported by his perfect moral conduct so that he is able to discover the meaning of the hidden entity. He becomes one with God. This final principle is a moral obligation and the main goal in the practice of kebatinan.

\section{BIBLIOGRAPHY}

AbDullah.

1971 August 1971. "Simbolik dalam Dewarutji dan Psikologi Yung", paper presented at Pusat Pewajangan Indonesia in Teater Arena Pusat Kesenian Djakarta, Taman Ismail Marquki, 3 August 1971.

ADHIKARA SP.

1984 Unio Mystica Bima. Bandung : ITB

Ciptoprawiro, AbDullah.

1986 Filsafat Jawa. Jakarta: Balai Pustaka.

Ciptoprawiro, AbDullah.

1988 Makna Widya Pandawa Moksa, in a special edition of Gatra; 7072.

Diwati, Retno.

1988. "Tinjauan Filosofis dan Serat Dewaruci". Dissertation for Literature Degree. Jakarta, Faculty of Letters, Universitas Indonesia.

De Yong. S.

1976. Salah satu Sikap Hidup Orang Jawa. Yogyakarta, Yayasan Kanisiuss.

MAgnis-SuSENo, Franz.

1982. Kita dan Wayang, Jakarta : Leppenas.

Magnis-Suseno, Franz.

1984. Etika Jawa. Jakarta : Gramedia. 
Mangkunagara VIII, K.G.P.A.A.

1933 "Over Wayang Kulit Purwa in het algemen en over de daarin voorkomende Symbolische en Mystie ke Elementen". Djawa Magazine: 89-95.

Mangkunagara VIII, K.G.P.A.A.

1957 On the Wajang Kulit (Purva) and it its Symbolic and Mystical Elements Translated from Dutch by Claire Holt. New York: Cornell University Press.

Mulder, Niels.

1983 Kebatinan dan Hidup sehari-hari Orang Jawa. Jakarta: PT Gramedia.

Poedjawijatna, I.R.

1983 Manusia dengan alamnya. Filsafat Manusia. Jakarta Bina Aksara.

Sastroamidjojo, A. Seno.

1964 Renungan tentang Pertunjukan Wajang Kulit. Djakarta: Kinta.

Sastroamidjojo, A. Seno.

1967. Dewa Rutji. Djakarta; Kinta.

SOEBARDI, S.

1975 The Book of Cabolek. The Haque: Martinus Nijhof

SOETARNO.

1977 'Le Role de La Musique dans Les Arts du Spectacle a Java" These de Doctorat de troisieme cycle. Paris: Universite Paris VII

SOETARNO.

1988. “Aspek filsafat dalam Pakeliran" Paper for Tenaga teknis Pamong Kesenian Depdikbud.

SOETARNO.

1988 "Perspektif Wayang dalam Era Modernisasi" Surakarta: ASKI Surakarta.

SOETARNO.

1988 "Unsur-unsur Estetis dalam Pedalangan Wajang Kulit Jawa Tengab” Surakarta: ASKI Surakarta.

SOETARNO.

2005 Pertunjukan Wayang dan Makna Simbolis. Surakarta : STSI Press.
SOETARNO.

2010 Teater Wayang Asia . Surakarta : ISI Press.

SoEtARno, SARWANTO.

2010 Pertunjukan Wayang dan Perkembangannya. Surakarta : ISI Press.

SRI Mulyono,

1979. Simbolisme dan Mistikisme dalam Wayang. Jakarta: Gunung Agung.

Sutrisno, Slamet., Kasidi H., Puriwadi, Joko

Siswanto., Mikka W.N, Iva Ariani .

2009 Filsafat Wayang. Yogyakarta : Sena Wangi.

SuRAhardjo, Y.A.

1983. Mistisisme. Suatu Introduksi di dalam Usaha Memahami Gejala Mistik Termasuk yang ada di Indonesia. Jakarta: Pradnya Paramita.

SUYANTO.

2009. Nilai Kepemimpinan Lakon Wabyu Makutharama .Surakarta: ISI Press.

TANOYO, R.

1979 Bima Suci. Jakarta: Balai Pustaka.

TRIMURTI, S.K.

1979. "Serat Dewaruci dan Pengertian Sufisme di Dalamnya" Warta Wayang 3 (1979): 1215. 